\title{
Binema bonaerensis n. sp. (Oxyurida: Thelastomatidae) Parasite of Neocurtilla claraziana Saussure (Orthoptera: Gryllotalpidae) in Argentina
}

\author{
Nora B Camino ${ }^{+}$, Guillermo R Reboredo ${ }^{++}$ \\ Centro de Estudios Parasitológicos y de Vectores, Cepave, Calle 2 № 584, 1900 La Plata, Argentina
}

The nematode Binema bonaerensis $n$. sp. (Oxyurida: Thelastomatidae) is described from the intestine of the mole cricket of Neocurtilla claraziana Saussure (Orthoptera: Gryllotalpidae) from Buenos Aires Province, Argentina. It is distinguished mainly by having a conical tail; three sclerotized arches in the buccal cavity; an excretory pore inmediately posterior to the base of the esophagus and the presence of five pairs of male genital papillae with one pair preanal and four pairs postanal.

Key words: Binema bonaerensis n. sp. - Thelastomatidae - mole cricket - Gryllotalpidae - parasite - taxonomy Argentina

Members of four species of Binema Travassos, 1925 (Nematoda: Thelastomatidae) are known: $B$. korsakowi (Sergiev 1923) parasitizing mole crickets in Russia, Brazil, India and Spain, B. ornata Travassos, 1925 from mole crickets in India, Spain and Brazil, B. mirzaia (Basir 1942) from mole cricket and cockroach in India and B. pseudornatum Leibersperger, 1960 from mole crickets in Germany. In Argentina, there is one species cited (Marchissio \& Miralles 1993), B. korsakowi Sergiev, 1923, parasitizing Neocurtilla claraziana Saussure. In Buenos Aires Province B. bonaerensis n. sp. was recovered from the intestine of fourthstage nymphs of the mole cricket $N$. claraziana feeding on zucchini, salt-wort, leek and onions.

\section{MATERIALS AND METHODS}

Fourth-stage nymphs of $N$. claraziana found in Gorina, Buenos Aires Province, were placed manually in individuals vials in the field. We followed the technique recommended by Poinar (1975): insects were thermally immobilized at $5^{\circ} \mathrm{C}$ for $10 \mathrm{~min}$. Dissections were performed under a stereoscopic microscope with the insects in distilled water in a Petri dish. Nematodes (males and females) were removed from the stomodea intestine of the insects and then they were killed in distilled water at $60^{\circ} \mathrm{C}$ for 2 min. Fixation was accomplished in two steps. First the nematodes were

\footnotetext{
${ }^{+}$Corresponding author. Fax: $+54-21-232327$. E-mail: cepave@isis.unlp.edu.ar

${ }^{++}$Profesional de Apoyo Conicet, Cepave.

Recieved 24 April 1998

Accepted 10 February 1999
}

placed in a solution of equal volumes of distilled water and TAF (1:1) for $48 \mathrm{hr}$. Final fixation was done in TAF for several days.

Both living and fixed specimens were used for the drawings and measurements using a camera lucida and ocular micrometer in a Zeiss compound microscope. Measurements are for the holotype male and allotype female with the ranges of the paratypes parenthesis. All measurements are give in micrometers $(\mu \mathrm{m})$ unless otherwise specified.

\section{RESULTS}

Genus Binema Travassos, 1925 Binema bonaerensis n. sp.

(Figs 1-8)

Description: small nematodes. Cuticle annulated throughout body length (Fig. 1). Mouth opening prismoidal, surrounded by eight submedial lip papillae and two pore-shaped amphids. Buccal cavity short and cylindrical with three sclerotized arches (Figs 1, 3). Esophagus with typical cylindrical corpus, short isthmus, and posterior valvular bulbous. Excretory pore immediately posterior to base of valvular bulb (Figs 1, 3). Vulva posterior to middle of body. Vagina cylindrical (Fig. 8). Two ovaries. Short, conical tail in female and male (Figs 4, 5, 7). Single spicule. Gubernaculum and bursa absent. Five pairs of genital papillae organized with one pair preanal and four pairs postanal (Fig. 4). Fertilized eggs oval (Figs 6, 8), paired in uterus, with several filaments at each pole. Male $(n=18)$ : body length $768(680-810)$. Cephalic diameter 18.8 (16-20). Esophagus length 134 (125.6-142). Distance from anterior end to excretory pore 185 (182-194). Greatest width 79.6 (7782.1). Spicule length 30.6 (29.5-32.2). Tail length $42.3(40.7-42.5)$. 

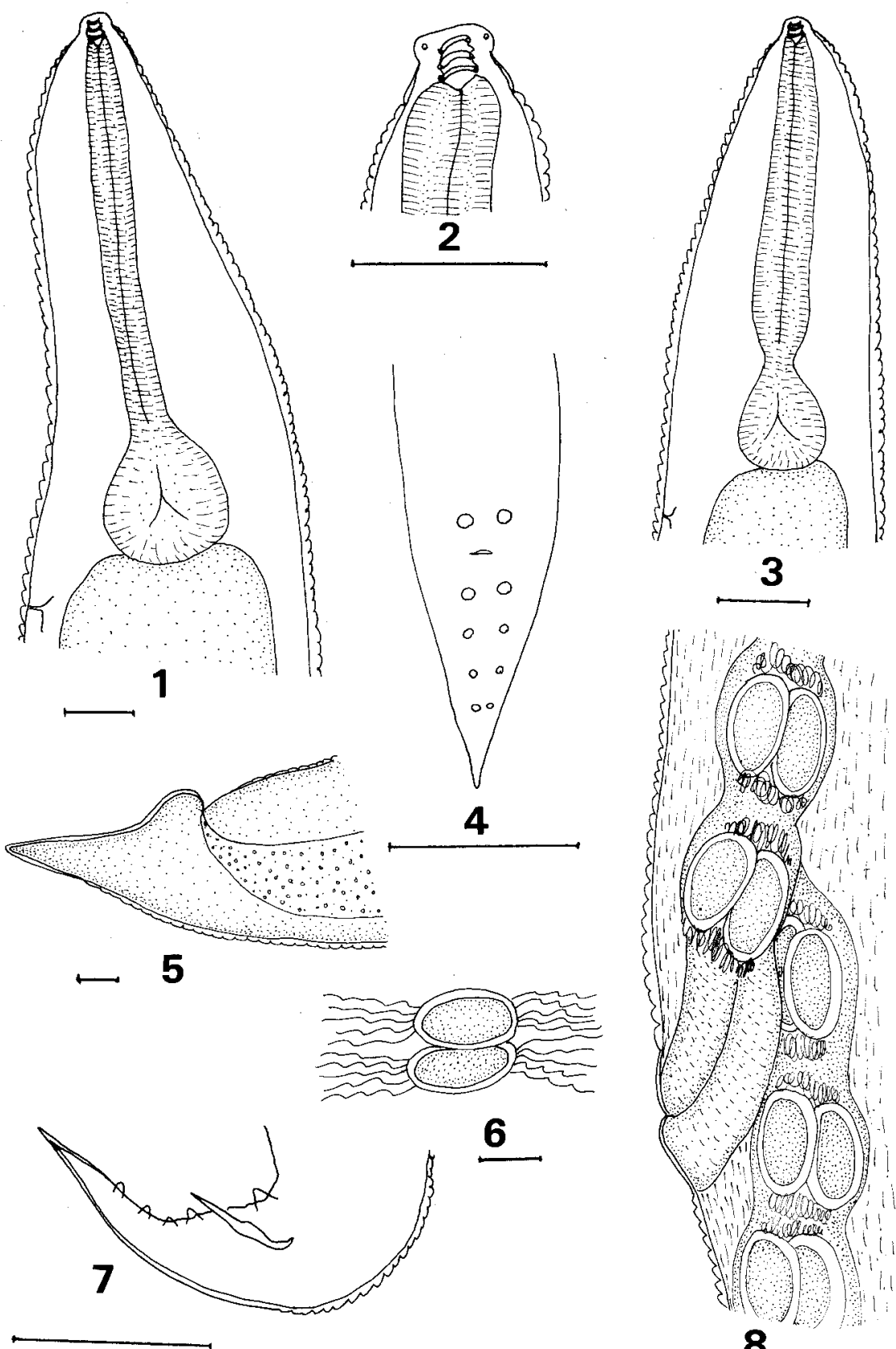

8

Binema bonaerensis n. sp. Fig. 1: anterior end of female, ventral view. Fig. 2: buccal cavity of male. Fig. 3: anterior end of male, ventral view. Fig. 4: posterior end of male, ventral view. Fig. 5: posterior end of female, lateral view. Fig. 6: eggs with terminal filaments. Fig. 7: posterior end of male, lateral view. Fig. 8: vagina and uteri bearing fertilized eggs. Bars $=50 \mu \mathrm{m}$.

Female ( $\mathrm{n}=20)$ : body length 1780 (1580-1980). Cephalic diameter 21.2 (18.8-23.5). Esophagus length 349 (333.7-364.3). Distance from anterior end to excretory pore 417.1 (411.3-423). Greatest width 212.7 (173.9-251.5). Vulva from the anterior end as a percentage of body length $64 \%$ (6365.2). Tail length 71.7 (68.2-75.2). Length and width of eggs 84.6 (63.5-105.8) x 36.4 (30.6-42.3). Type host: fourth instar nymphs of Neocurtillia claraziana Saussure, 1874 (Orthoptera: Gryllotalpidae).

Type location in host: intestine.

Type locality: Gorina, Buenos Aires Province, Argentina. 
Type material: deposited in the Helminthological collection at Cepave, serie numbered TB123TB125.

\section{DISCUSSION}

Four species of Binema have been described: B. korsakowi (Sergiev 1923) Basir, 1956; B. ornata Travassos, 1925; B. mirzaia (Basir 1942) Basir, 1956; and B. pseudornatum Leibersperger, 1960. The four species are very similar in having a prismoidal mouth opening surrounded by eight submedial lip papillae and two pore-shaped amphids, an excretory pore immediately posterior to the esophagus bulbous, and the vulva posterior to the middle of the body.

$B$. bonaerensis $\mathrm{n}$. $\mathrm{sp}$. with the male conical tail and caudal papillae with only one pair preanal and four pairs postanal is unique. B. pseudornatum is known only from female specimens and is thus an incompletely described species. The other three species can be separated from B. bonaerensis $\mathrm{n}$. sp. on the basis of male tail characteristics. B. korsakowi has a short, spine-like caudal appendage and nine pairs of caudal papillae-five pairs preanal papillae and four pairs postanal. B. ornata males have a long filiform tail and eight pairs of caudal papillae-four pairs preanal and four pairs postanal. B. mirzaia has a long and evenly tapered tail with ten pairs of caudal papillae-four pairs preanal, three pairs adanal and three pairs postanal.

\section{REFERENCES}

Basir MA 1942. Nematodes parasitic in Gryllotalpa. Rec Ind Mus 44: 92-106.

Basir MA 1956. Oxyuroid parasites of Arthropoda. Zoologica 38: 1-79.

Leibersperger E 1960. Die Oxyuroidea der euroäischen Arthropoden. Parasitol Schriftenr 11: 1-150.

Marchissio SL, Miralles DAB de 1993. Talpicola klossae sp. n. y nuevo registro de Binema korsakowi (Sergiev, 1923) (Nematoda: Thelastomatidae) parásitos de Neocurtilla claraziana (Orthoptera: Gryllotalpidae). Neotrópica 39: 79-82.

Poinar Jr GO 1975. Entomogenous Nematodes. A Manual and Host List of Insect Nematode Associations, EJ Brill, Leiden, 317 pp.

Sergiev PG 1923. Two new nematodes from the intestine of Gryllotalpa vulgaris. Rapport de $21^{\circ}$ seance de la commission pour l'étude de la faune helminthologique de Russie 1923. Trans State Inst Exp Vet Sci Moscow 1: 183-190.

Travassos L 1925. Quelques nematodes du Gryllotalpa. Cr Soc Biol 93: 140-141. 
